\title{
ARGUMENTS OR MACROROLES? TWO FUNCTIONAL APPROACHES TO OLD ENGLISH QUIRKY CASE
}

\author{
JAVIER MARTÍN ARISTA \\ LAURA CABALLERO \\ Universidad de La Rioja
}

\begin{abstract}
After comparing two functional approaches to the question of Old English deviant accusatives, genitives and datives, this paper follows Martin Arista (2001a, b) with respect to Old English prototypical verbal constructions: the prototypical transitive construction is defined as the active accomplishment version of verbs like writan 'write', the activity implementation of creation and consumption verbs representing the less-prototypical transitive construction; the active accomplishment use of verbs such as faran 'go' characterize the prototypical intransitive construction, whereas the activity version of motion verbs define the less-prototypical intransitive construction. The conclusion is reached that quirky case is not a feature of the morphosyntax of certain intransitive verbs of state and causative state, but a characteristic of verbal constructions that, deviating from both the transitive and the intransitive prototypes, show not only case-marking irregularity but also more case-marking choices than verbs that abide by the transitive or intransitive prototype. Since marked morphosyntax -including quirky case- is considered in this paper a consequence of the non-prototypical character of argument structure, it is claimed that the relationship between canonical lexical templates and their configurations should be semantically and syntactically motivated. The Principle of Lexical Template Instantiation guarantees the suitable degree of implementation of a lexical template by stipulating that, prototypically, all the internal variables of the instantiations of lexical templates are fully specified.
\end{abstract}




\section{INTRODUCTION}

For nearly two decades, Functional Grammar (henceforth FG) has been compared with other linguistic theories. Since the publication of the volume edited by Hoekstra, van der Hulst and Moortgat (1981), several studies have engaged in the cross-theoretical treatment of various aspects, which has contributed to the consideration of some unexplored grammatical domains, thus heating the debate among FG scholars. More importantly, theory comparison has made for the sense of a collective functional enterprise, which, in turn, has started to give the atmosphere of a dynamic functional-cognitive community. Works like Goossens (1990a) and Nuyts (1992), among others, have helped fill in the gap between functionalism and cognitivism, while the comparison of FG and other functional and cognitive theories carried out by Butler (1990), Kalisz and Kubinski (1997) and Martín Arista (1999), to quote just some recent studies, has shed light on certain methodological and theoretical areas. Theory comparison turns out even more stimulating if, as is the case with this paper, some potential points of convergence have already been succesfully explored and exploited. Van Valin (1990), Butler (1996) and Mairal and Van Valin (2001) have pointed out a number of coincidences and compatibilities between FG and Role and Reference Grammar (hereafter RRG), while acknowledging the more semantically-oriented character of the former and the more syntactically-aimed nature of the latter. As regards the similarities between the two theories it suffices to stress the intertwined development of layered clause structure in Dik (1978), Foley and Van Valin (1984), Hengeveld (1989, 1990) and Van Valin and LaPolla (1997), to cite the most representative pieces of research.

\section{RESTRICTIONS ON ARGUMENT STRUCTURE}

This paper follows in the wake of Faber and Mairal (forthcoming), according to whom "syntactic variation can be explained by modeling processes which operate upon the canonical lexical template through the application of lexical rules, which relate lexical entries to their complement configurations". In raising the issue of Old English quirky case, we intend to bear on a syntactic facet of the relationship between canonical lexical templates and their configurations, namely the impact on morphological case of the degree of prototypicality of argument structure (we use the term argument structure to refer to both argument valence and macrorole valence, despite the differences between the FG and RRG approaches in this respect, on which we focus below in this section). By eleborating on Taylor (1989: 211) we define the prototypical transitive and intransitive construction and formulate The Principle of Lexical Template Instantiation, which accounts for 
the mappings between a lexical template and the different degrees of implementation of a syntactic configuration. We deal with these aspects in section 6. Sections 3 and 4 are concerned with Old English quirky case in RRG and FG respectively, while section 5 shows why the scope and nature of this phenomenon should be reconsidered. ${ }^{1}$

The remainder of this section discusses the nature of the restrictions imposed on argument structure, which we consider semantic in FG and syntactic in RRG. Argument structure in FG is valency-based: the number of arguments equals the quantitative and qualitative valency of the verbal predicate. Given a verb like 'drink' in example (1), the FG analysis of argument structure is the same for (1.a), (1.b) and (1.c): the verbal predicate displays quantitative valency two which is reduced to one in the case of the linguistic expression (1.a), where the second argument is underspecified as a result of the application of a rule of second argument reduction (Dik 1997: 14):

\section{(1)}
a. Maria was drinking
b. Maria was drinking beer
c. Maria was drinking a pint of beer

If we consider the qualitative valency, the semantic function Agent of (1.a), (1.b) and (1.c) is borne by the first argument, and the Goal of (1.b) and (1.c) by the second argument. The restrictions imposed on the notion of argument in FG are semantic in nature: Dik's (1989: 103) algorithm of argument structure restricts the possible combinations of semantic functions, limits the range of functions of the first, the second and the third argument, and defines some incompatibilities.

Argument structure in RRG is macrorole-based. Like the semantic notion of argument, the semantic-syntactic notion of macrorole originates in a generalization across semantic roles. In Van Valin and LaPolla's (1997: 139) words, "macroroles are generalizations across the argument-types found with particular verbs which have significant grammatical consequences; it is they, rather than specific arguments in logical structure, that grammatical rules refer to primarily". The main question is what is coded by the grammar in the same or in a different way: the generalized agent-type role receives the same grammatical treatament, which is, in turn, different from the grammatical treatment of the generalized patient-type role. Going back to example (1), whereas syntagmatic considerations do not impose restrictions on argument

1. The following abbreviations are used in this paper: NOM (nominative), ACC (accusative), GEN (genitive) and DAT (dative). 
structure in FG, macrorole assignment in RRG is determined by the syntactic realization of sentences. The logical structure of (1.a), (1.b) and (1.c) is linked to the syntax by means of the assignment of the ACTOR macrorole to the thematic relation Effector in (1.a) and the assignment of the ACTOR to the thematic relation Consumer in (1.b) and (1.c). Macrorole assignment is transparent in (1.a) and (1.c): one argument gets one macrorole in (1.a) and a quantitative valency of two is associated with the assignment of both ACTOR and UNDERGOER in (1.c), the UNDERGOER being licensed by the thematic relation Consumed. On the other hand, macrorole assignment is opaque in (1.b) because only fully referential noun phrases are privy to macrorole status. Leaving aside discourse considerations, reference manifests itself in noun phrases through the presence of grammatical operators of definiteness, deixis, count-mass, etc. As we show in section 6, the kind of macrorole alternation that results from the presence or absence of telicity in the logical structure is the determinant for the degree of prototypicality of the transitive and the intransitive construction.

This sort of syntactic restriction justifies the distinction drawn in RRG between valency and transitivity: valency is a function of the semantics of the verb whereas transitivity is determined by the syntax of the construction into which the verb appears. This aspect confers a privileged status to macroroles, which guarantee the linking between semantics and syntax thus enjoying explanatory status: whereas grammatical rules tend to make reference to the functions performed by the arguments of the verb rather than to the argument itself in FG, grammatical rules make reference to the syntactically-restricted macroroles. Case theory could not be an exception in this respect. For this reason, we have chosen this particular area of the grammar to illustrate our point. Since inflection is marginal in Contemporary English, we have opted for Old English. In the next two sections we demonstrate that the scope of Old English deviant or quirky case is wider than shown by Roberts (1995). We also compare some aspects of case theory in FG and RRG with respect to quirky accusatives and genitives in Old English. The conclusion is reached that FG and RRG give different weight to case theory: case is a product of the expression component of FG whereas it turns out of much more significance to the semantics-syntax linking in RRG.

\section{OLD ENGLISH CASE IN RRG}

Looking at case theory in RRG in the first place, Van Valin (1991: 181) puts forward the case marking rules in (2) for accusative languages: 
(2)

a. Highest ranking macrorole gets NOMINATIVE case

b. The other macrorole argument gets ACCUSATIVE

c. Non-macrorole arguments take DATIVE as their default case

Case marking in Old English, an accusative language, can be explained in an ingenuous and elegant way by means of the algorithm in (2) in the vast majority of expressions. Three examples follow:

(3) $<$ B COCHROA2 $><$ R 465.1 $>^{2}$

Her Hengest \& æesc gefuhton uuid Walas

here Hengest and $Æ s h_{i^{-}}$NOM fought with Welsh

neah Wippedesfleote,

near Wippedesfleet,

\& dxer xii Wilisce aldormenn ofslogon

and proi there twelve Welsh earls killed

This year Hengest and Esh fought against the Welsh near Wippedesfleet and killed twelve Welsh earls there

In example (3) the Agent participant Hengest \& oesc 'Hengest and Æsh' licenses the ACTOR macrorole, which, being the only macrorole available from the macrorole-intransitive verb gefeohtan 'fight', gets nominative case marking.

(4) $<$ B COPREFCP $><$ R 15>

da ongan ic ongemang odrum mislicum \& manigfealdum

then began $\mathrm{I}_{\mathrm{i}}$ among other various and manifold

bisgum disses kynerices da boc wendan

concerns of this kingdom proi the book-ACC to translate

on Englisc de is genemned on Læeden Pastoralis

into English that is called in Latin Pastoralis

I began, among other various and manifold concerns of this kingdgom, to translate into English the book entitled Pastoralis in Latin

In example (4) the pro element which is coreferential with the first person singular personal pronoun gets the ACTOR macrorole, which outranks the UNDERGOER in the macrorole hierarchy. Consequently, the participant Ic ' $\mathrm{I}$ ' is declined in nominative while $\partial a$ boc 'the book' is case-marked accusative.

2. Examples taken from the diachronic part of the Helsinki Corpus of English, compiled by Rissanen \& Ihalainen (1984). The text reference system of the Helsinki Corpus has been kept. Whenever examples have been extracted from a secondary source, the source is acknowledged between brackets and the same text reference system is followed as in the secondary source. Note that BT stands for Bosworth and Toller's Anglo-Saxon Dictionary. 
(5) $<$ B COCHROA $><$ R 874.5>

$\& \partial y$ ilcan geare hie sealdon anum unwisum cyninges

and this same year they gave an unwise king's

degne Miercna rice to haldanne, \& he him

thane $_{i}$-DAT Mercian kingdom pro $_{i}$ to hold, and he them

adas swor \& gislas salde, dxt he him

oaths swore and hostages gave that it them

gearo wære swa hwelce dæge swa hie hit habban wolden

ready would be any day that they it have wished

And the same year they gave the kingdom of Mercia to an unwise thane of the king's, and he gave them hostages and swore them oaths that it would be ready for them any time they wished to recover it

In example (5) the direct core argument anum unwisum cyninges degne 'an unwise king's thane' is denied macrorole status thus receiving by default dative case. In this example there is no macrorole available because hie 'they' gets ACTOR and nominative case while Miercna rice 'the kingdom of Mercia' achieves UNDERGOER status and is case-marked accusative. This macrorole assignment needs further clarification: in Contemporary English the UNDERGOER goes to the object of ditransitive verbs that, being morphologically unmarked, follows the verb in the linear order of the clause. The morphologically marked object of Contemporary English is a candidate for 'undergoerhood' and, consequently, privileged syntactic argument, or PSA, of the corresponding passive, provided that certain morphosyntactic requirements of marking and position are satisfied. Since there were not passives like An unwise king's thane was given the kingdom of Mercia in Old English, the direct core argument anum unwisum cyninges degne is not a candidate for 'undergoerhood'. Given that it is a direct core argument of the verb, it bears the dative case.

The analysis of case marking in examples (3), (4) and (5) draws attention to three characteristics of the RRR case marking algorithm: in the first place, the RRG case marking algorithm relies on two basic distinctions, namely macrorole vs. non-macrorole status and direct vs. oblique argument status; in the second place, the nominative rule is based on agreement and the accusative rule on the passive construction; and, in the third place, case is dissociated from syntactic function as well as from semantic function: this could not be otherwise because the split theory of grammatical relations advanced in Van Valin and LaPolla (1997) does not allow for crossconstruction generalizations; on the contrary, grammatical relations are construction-dependent, in such a way that each of them may have its controler and/or its pivot. In example (3) the ACTOR argument case-marked nominative is the PSA of the construction because its control properties include agreement with the finite verb, thus functioning as a syntactic 
controller. If we consider the second part of the coordinate subject deletion construction in (3), E joer xii Wilisce aldormenn ofslogon 'and [they] killed twelve Welsh earls there', the PSA constitutes a pragmatic pivot not only because it assigns reference to the pro element but also because switchfunction is possible, given that the syntactic pivot is the ACTOR in Hengest and Esh killed twelve Welsh earls and the UNDERGOER in Twelve Welsh earls were killed by Hengest and Æsh. The ACTOR argument case-marked nominative of (4) is also the PSA of the construction, but, by contrast, it involves not only a semantic controller that assigns reference to the pro element, but also a syntactic pivot performed by the noun phrase omitted in the construction. There is also a semantic controller in example (5) but it does not overlap with the syntactic pivot, which is performed by the compulsory objective gap that follows the inflected infinitive to haldanne 'to hold'.

Roberts (1995: 168) argues that the algorithm in (2) explains Old English case marking if two provisions are made: first, there are non-macrorole PSAs, in Old English; and second, genitives are not direct core arguments in Old English but obliques of some sort (Roberts 1995: 176). Allen (1995: 55) furnishes evidence for the existence of non-macrorole PSAs in Old English. ${ }^{3}$ She demonstrates that Old English subjects are seldom deleted unless they are coreferential with the first subject of a coordination construction, as is shown by (6):

(6) <Alc. P. xx.71> (Allen 1986: 390)

ac gode ne licode na heora geleafleast

but Godi-DAT not liked their faithlessness-NOM

ac sende him to fyr of heofonum

but proi sent them to fire of heaven

But God did not like their faithlessness, but sent them fire from beaven

According to the case marking algorithm in (2) gode 'God', being a direct core argument of lician 'like' does not bear macrorole and, consequently, gets dative case marking as default. However, gode is the PSA in the coordinate subject deletion construction exemplified by (6). If we consider the first clause, the dative gode is a syntactic controller because it determines the agreement in person and number with the finite form of the verb licode 'liked'. Moreover, if we analyse the whole construction, gode is a pragmatic pivot given that it controls the omission of the coreferential noun phrase on the grounds of the degree of accessibility in discourse of topical elements. Along with the existence of non-macrorole PSAs, Roberts (1995: 179) finds the other exceptional feature of Old English case in the existence of quirky accusatives like that of example (7.b):

3. See also Fischer et al. (2000: 44ft). 
(7) (Mitchell 1985: 428)

a. <Ælfric, Hom I, 166, 12>

Him hingrode

him-DAT was hungry

He was hungry

b. <Wulfstan, Hom. 17, 4>

Hine dyrste

him-ACC was thirsty

He was thirsty

The atransitive verb hyngrian 'be hungry' licenses no macrorole. Consequently, the non-macrorole direct core argument is case-marked dative by default and the case marking algorithm given in (2) explains the presence of the dative in (7.a), but not of the accusative that accompanies the verb "yrstan 'be thisty' in (7.b). Roberts (1995: 180) remarks that quirky accusatives in Old English appear only in active atransitive clauses, probably because this is the only context where confusion with the regular (UNDERGOER) accusative can be avoided. Roberts (1995: $180 \mathrm{ft}$. 25) goes on to say that the two accusatives are in complementary distribution: if there is no nominative, an accusative cannot be UNDERGOER; if a nominative is present, an accusative in the same sentence receives UNDERGOER. Datives never mark a macrorole, so, even though they appear in sentences with or without nominatives, confusion never arises. Atransitive verbs provide more evidence in favour of the existence of non-macrorole PSAs in Old English: the dative and the accusative of atransitive verbs control person and number agreement. Moreover, instances like (8), where coordinate subject deletion involves byngrian 'be hungry' and dyrstan 'be thirsty', present us not only with a syntactic controller but also with a pragmatic pivot, thus containing a non-macrorole PSA, namely bim 'he':

(8) $<$ B COAELHOM $><$ R 256.26>

Him hingrode and $\partial y$ rste

him $_{\mathrm{i}}$-DAT was hungry and pro $_{\mathrm{i}}$ was thirsty

He was bungry and thirsty

So far, Roberts's (1995) analysis is consistent with the data. However, when certain alternations of dative and genitive with two-place verbal predicates are taken into account, it does not seem out of place to widen the scope of Old English quirky case. Let us consider example (9):

(9) (BT)

a. <Hy. 7, 44>

Du monegum helpst

you many-DAT help 
You help many people

b. $<$ Swt. $45,5>$

donne $\partial u$ hulpe min

when you helped me-GEN

When you belped me

The verb belpan 'help' takes either a dative, as in (9.a) or a genitive, as in (9.b). The case marking rules for Old English as supplied by Roberts (1995) predict that the non-macrorole direct core argument gets dative case marking in (9.a) and that the oblique argument gets genitive case marking in (9.b). Both the dative in (9.a) and the genitive in (9.b) are denied PSA status because the ACTOR macrorole controls agreement. According to Roberts (1995: 176), genitive noun phrases cannot be PSAs because there are no active verbs in Old English whose only argument is a genitive and because two-argument verbs with a genitive object do not admit passivization. This is a fundamental difference with respect to datives, given that two-argument verbs with a dative passivize and preserve dative case-marking, as is shown by examples (10.a) and (10.b):

(10) (Denison 1993: 104)

a. $<$ CP 225.22>

Ac dæm mæg beon suide hrade geholpen from his lareowe but that-DAT may be quickly helped by his teacher But that one may be quickly helped by his teacher b. <ÆC Hom I 3.52.31>

...on urum agenum dihte hu us bid at Gode gedemed

...in our own power how us-DAT is by God judged

...in our own power as to how we shall be judged by God

The kind of data that Roberts (1995) seems to have missed is provided by examples like (11), in which the personal pronoun is case-marked genitive both in the active and in the passive:

(11) <Bo. 67.11> (Mitchell 1985: 355)

Fordæm se de his

for that cause he who him-GEN

xr tide ne tiolad,

before the time does not provide

donne bid his on tid untilad

then is he-GEN in time unprovided

Whoever does not provide himself beforehand will be unprovided when the time comes

In the light of instances of preservation of genitive case marking in the passive like (11) some behaviour properties of genitive noun phrases arise that 
stress the partial overlapping of genitive and dative case marking. Example (9) has illustrated the alternation of dative and genitive as second argument with two-argument verbs. Such alternation is also present in three predicate verbs, as (12) shows:

(12) (McLaughlin 1983: 12)

a. <Beowulf, 384>

Ic dæm godan sceal for his modzræce madmas beodan I the good-DAT shall for his daring treasures-ACC offer

I shall offer the good man treasures for his daring

b. <Chronicle, Anno 755>

Her Cynewulf benam Sigebryht his rices

here Cynewulf deprived Sigebryht-ACC his kingdom-GEN

This year Cynewulf deprived Sigebright of his kingdom

The evidence in (11) and (12) suggests that considering the genitive an oblique of some sort, as Roberts (1995) does, may ignore some significant facts, including complementation alternation and, more importantly, PSA status in a passive (following Foley and Van Valin's (1984) terminology, OE has a foregrounding passive, involving a marked linking macrorole-syntactic function, that is, a non-ACTOR PSA). Although we have not quantified the preservation of genitive case-marking in passivization, the evidence considered here is sufficient to state that Old English quirky case in RRG should include not only accusative noun phrases as only arguments of atransitive verbs but also genitive noun phrases as second arguments of -at least certain intransitive/transitive verbs.

\section{OLD ENGLISH CASE IN FG}

In a more syntactically-oriented theory like RRG case marking plays a much more significant role than in FG because it represents an outstanding feature of some complex constructions like coordinate subject deletion, raising or control, among others, which constitute one of the main concerns of RRG. Therefore, case marking -either predictable or quirky- is dealt with at the semantics-syntax linking algorithm, primarily in terms of macrorole assignment and secondarily by means of the distinction drawn between arguments and non-arguments. A practical consequence of this different attitude towards the question of case has been the relatively low number of studies dealing with case in FG. There is, to our knowledge, no previous research in deviant case marking in Old English in FG. ${ }^{4}$ We give a blueprint of what the treatment of Old English case in FG might be like by drawing on Dik (1989) and Pinkster

4. But see Martín Arista (2001a, b). 
(1990). The first conclusion that follows from the proposals by these authors is that the notion of quirky case is not very relevant to FG: if we have interpreted correctly Dik and Pinkster, FG would favour a treatment in terms of prototypical case marking that originates on systematic function-expression relationships and of lexically-specified non-prototypical case. In other words, lexical rules would account for what argument number, semantic function and syntactic function cannot explain. A preliminary proposal for Old English case marking would go along the lines given in (13):

(13) Old English case in FG (preliminary)

$$
\text { A1 A2 }
$$

1-place NOM

$$
\begin{aligned}
& \text { DAT (7.a) } \\
& \operatorname{ACC}(7 . b)
\end{aligned}
$$

2-place NOM

DAT (14)

ACC

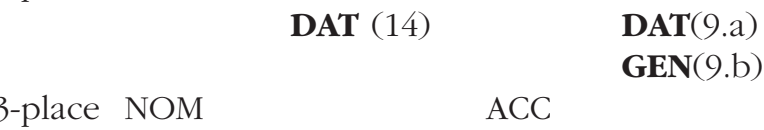

DAT (12.a)

DAT (15)

GEN(12.b)

ACC (16)

Note that numbers between brackets refer to examples in this paper Lexically-specified case is displayed in bold type. Instances of dative first argument with a two-place verb, a dative second argument with a three-place verb, and an accusative third argument with a three-place verb are given in (14), (15) and (16) respectively:

(14) (Allen 1995: 49)

<Ælc. Th.I. p. 192.16>

Him ofhreow dæs mannes

him-DAT pitied of the man-GEN

He felt sorry for the man

(15) $<$ B COBEOWUL $><$ R 2134 $>$

He me mede gehet

He me-DAT reward-DAT promised

He promised me a reward

(16) $<$ B COBEOWUL $><$ R 3079 $>$

Ne meahton we gelæran leofne deoden

not could we give the beloved chieftain-ACC

rices hyrde-ACC ræd ænigne-ACC

kingdom's keeper advice any

We could not give the beloved chieftain, the keeper of the kingdom, any advice 
In order to recapitulate, the preceding comparison has shown that FG and RRG differ in the importance they give to case theory: case constitutes a product of the expression component of FG whereas it is intimately associated with the linking semantics-syntax in RRG. It is the nature of the restrictions imposed on argument structure, semantic in FG and syntactic in RRG, that ultimately determine the more central or more peripheral nature of case in the grammar. Whereas FG associates case marking primarily with function and only secondarily with the argument that performs a given function in a predication, RRG treats case by means of syntactically restricted generalizations across thematic roles. On the side of similarities, there appear to be exceptions to case marking rules regardless of whether they are explained on the grounds of function assignment, as in FG, or by making reference to semantic macroroles, as happens in RRG. As Dik (1989: 315) puts it, "using a limited set of cases for a great variety of semantic and syntactic functions is thus a form of system economy which is bought at the price of occasional clashes". If the preliminary account of Old English case marking in (13) is correct and worth further consideration, convergence between the two functional theories may increase in the sense that case expression is motivated by argument structure. However, any attempt to highlight the similarities between FG and RRG with respect to argument structure should not neglect the fundamental fact that, apart from the restrictions on which we have commented in section 2, the First Argument corresponds to the ACTOR macrorole of transitive constructions and to the UNDERGOER of intransitives like:

\section{(17)}

a. Janet is bright

b. Phil fell on the slippery floor

c. The ice cube melted in a second

This difference between the two functional approaches, which is dealt with in more detail in Mairal and Van Valin (2001), precludes further convergence, but it also indicates that more research is needed in this area.

Leaving aside argument structure, it would also be possible to link case expression to syntactic function for nominative and accusative and to semantic function as far as genitive and dative are concerned, but this kind of linking tends to ignore the verbal dimension of the genitive, which is often characterized as a prototypical possessor within terms (Dik 1989: 313), as well as to miss the covert syntactic function of the dative.

\section{DISCUSSION}

Whenever the topic of quirky case is raised, one feels tempted to take the Sapirian line that all grammars leak. We have not resited the temptation in the 
belief that the classics provide us with particularly acute and challenging insights into some intricate areas of language. If quirky case constitutes an instance of leakage in the grammar of Old English, the issues at stake are: whether quirky case blurs fundamental functional distinctions or not, what does leakage involve, and what verbal constructions undergo quirky case.

With reference to the question if quirky case blurs functional distinctions, the answer is that it does not. The redundant nature of case marking in Old English is easily demonstrated by focusing on the increasing importance of other structural devices like prepositional marking and rigid word order several centuries before the case system was reduced to the marginal character it has in Contemporary English. Another argument for the relatively low distinctive value of case marking in Old English may be found in the considerable degree of case syncretism displayed by nominal and adjectival declensions, particularly in their weak patterns. Still another argument in favour of the relatively low functional rank of case marking in Old English is that as early as in Beowulf there are numerous instances of irregular case marking which Pyles and Algeo (1982: 152) attribute to the process of levelling of unstressed vowels which was well under way by the year 1000. The whole argument aims in the direction of Pinkster's (1990: 62) remark that "linguistic structures contain more information than is strictly necessary (...) This serves to guarantee successful communication or (..) to compensate for the lack of non-verbal means of communication".

\section{TRANSITIVITY PROTOTYPES AND THEIR IMPLICATIONS FOR LEXICAL REPRESENTATION}

As for the second question, leakage often involves different possibilities of expression. As we have seen in the examples above, quirky genitive distributes with predictable dative in verbal constructions with helpan 'help'; and quirky accusative co-occurs with predictable dative in constructions with verbs like hyngrian 'be hungry' and dyrstan 'be thirsty'. Moreover, these verbs also admit expression in nominative, as can be seen in (18):

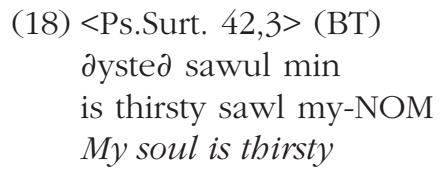

State verbs like dyrstan 'be thirsty' are atransitive, that is, they license no macrorole, which rules out the assignment of nominative case-marking to sawul min 'my soul' in (18) on the grounds of the case-marking algorith in (2). Nominative case is therefore quirky: what the algorith predicts for non- 
macrocole PSAs is dative, not nominative case-marking. This reinforces the argument in favour of an enlargement of the scope of quirky case in Old English.

As regards the type of verbal constructions with which quirky case is associated, one should not miss the point that quirky case appears in connection with states and causative states. ${ }^{5}$ As Michaelis (1993: 311) has demonstrated in her study in deviant case-marking in Latin, "where two-place predicates depart from the nominative-accusative pattern (...) these deviations are to be attibuted to the verb's intransitive nature -unexpected given the number of verbal arguments". We agree with Michaelis on the role played by the nature of the verb, but we depart company with her with reference to the issue of transitivity: quirky case is not a feature of the morphosyntax of certain intransitive verbs of state and causative state, but a characteristic of verbal constructions that, deviating from both the transitive and the intransitive prototypes, show not only case-marking irregularity but also more casemarking choices than verbs that abide by the transitive or intransitive prototype. Although I draw on Taylor's (1989: 211) notion of the prototypical transitive construction, we offer a syntactic definition of this notion instead, as well as a proposal for the syntactic prototype of intransitive construction. ${ }^{6}$ In our opinion, macrorole alternation with verbs of creation and consumption defines the prototypical transitive construction; while macrorole alternation with verbs of motion defines the prototypical intransitive construction. Let us consider the following examples with writan 'write' and swimman 'swim":

a. $<$ B COMARTYR $><$ R 2234>

He wrat $\partial$ a maran boc actus apostolorum

he wrote the great book Actus Apostolorum

He wrote the great book entitled Actus Apostolorum

b. $<$ B COWSGOSP $><$ R 8.6>

Se Hælend abeah nyder

the saviour bent down

\& wrat mid his fingre on $\partial æ r e ~ e o r \partial a n$

and wrote with his finger on the earth

The Saviour bent down and wrote with his finger on the earth

5. From the point of view of FG, Old English quirky case in general and the previous account in particular represent a contribution to the discussion whether the typology of States of Affairs should be modified to include the feature [ \pm Cognizant], as Goossens (1990b) puts forward. The crux of the matter is that morphosyntactic irregularity results from lack of semantic prototypicality. Quirky case verbs do not conform to the semantic definition of the prototypical transitive construction as rendered in Taylor (1989: 206).

6. Semantically, Talmy's (1988) notion of Force Dynamics accounts for the compulsory expression of participants directly involved in the event chain. 
c. $<$ B COALEX $><$ R 293>

Hie on sunde to dære byrig foron

they in the water to that town went

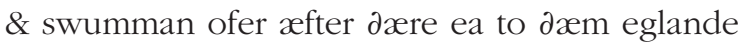

and swamm over through that river to the island island

They went to that town across the water and swam across the river to the

d. $<$ Lchdm. iii. 272, 19> (BT)

Swa swa fixas swimmad on wæetere

as fish swimm in water

As fish swimm in water

The active accomplishment version of verbs like writan 'write' in (19.a) constitute the prototypical transitive construction, the activity implementation of creation and consumption verbs representing the less-prototypical transitive construction, as in (19.b); the active accomplishment use of verbs such as faran 'go' and swimman 'swim' in (19.c) characterize the prototypical intransitive construction, whereas the activity version of motion verbs define the less-prototypical intransitive construction, as is illustrated by (19.d). It follows that constructions with state and causative state verbs are nonprototypical, either as transitive or intransitive; and that achievements and underspecified activities constitute non-prototypical instances of the intransitive construction. This is tantamount to saying that macrorole alternation as a result of the presence or absence of the feature [ \pm telic] in t'he logical structure defines verbal construction prototypicality. Notice that the participants coded by means of the constituents da maran boc actus apostolorum 'the great book entitled Actus Apostolorum', to daere byrig 'to that town' and to doem eglande 'to the island' in (19.a) and (19.c) respectively contribute the feature of telicity.?

The definition of the prototypical verbal construction in terms of macrorole alternation contributes to Faber and Mairal's (forthcoming) proposal of lexical rules which relate lexical entries to their complement configurations. Since marked morphosyntax -including quirky case- reveals itself as a consequence of the non-prototypical character of argument structure, the relationship between canonical lexical templates and their

7. Kiparsky (1998: 266) remarks that the function of the partitive that alternates with the accusative as the object of some verbs in Finnish is "to license unboundedness at the VP level". Although this study shares with Kiparsky's the focus on the relationship between external aspect and morphosyntactic case, we consider telicity the decisive criterion, whereas Kiparsky (1998: 268) takes the line that "what is relevant is the gradability of the event: bounded predicates, whether telic or atelic admit of no degree". 
configurations should be semantically and syntactically motivated. More specifically, a functional principle should guarantee the suitable degree of implementation (that is, of specification of internal variables of a given instantiation) of a lexical template. The Principle of Lexical Template Instantiation stipulates that, prototypically, all the internal variables of the instantiations of lexical templates are fully specified:

(20) The Principle of Lexical Template Instantiation

Lexical templates tend to map maximal implementations onto syntactic structures, in such a way that isomorphism between semantic participants and syntactic constituents is maximized

This functional principle is compatible with Van Valin and LaPolla's (1997: 325) Completeness Constraint, which accounts for the linking between semantic participants and syntactic constituents, but applies previously. If the reasoning is correct, lexical templates and their syntactic configurations present an interesting contrast: syntactic configurations involve variable and/or operator reduction from lexical templates (Faber and Mairal, this volume); whereas they favour maximal implementations in both transitive and intransitive contructions, thus avoiding variable reduction.

\section{REFERENCES}

Allen, C. L. 1986. "Reconsidering the history of 'like". Journal of Linguistics 22: 375-409.

Allen, C. L. 1995. Case Marking and Reanalysis: Grammatical Relations from Old to Early Modern English. Oxford and New York: Clarendon Press.

Butler, C. S. 1990. "Functional Grammar and Systemic Grammar: a preliminary discussion". Working Papers in Functional Grammar 39. Amsterdam: University of Amsterdam.

The research reported here was funded by the Dirección General de Enseñanza Superior e Investigación Científica through the Estancias de investigadores españoles en centros de investigación extranjeros programme. Additional funding was provided through the grant PI1999/136, entitled Diccionario nuclear sintáctico de base temática del léxico en inglés antiguo, whose main researcher is Francisco Cortés Rodríguez. We should like to thank Robert Van Valin for his thorough revision and useful comments on several sections of an earlier version of this paper. The usual disclaimers apply. 
Butler, C. S. 1996. "Layering in functional grammars: a comparative survey", in: B. Devriendt, L. Goosens, and J. van der Auwera (eds.), Complex Structures. A Functional Perspective. Berlin: Mouton. 1-27.

Denison, D. 1993. English Historical Syntax: Verbal Constructions. London and New York: Longman.

Dik, S. C. 1978. Functional Grammar. Dordrecht: Foris.

Dik, S. C. 1989. The Theory of Functional Grammar. Part 1: The Structure of the Clause. Dordrecht: Foris.

Dik, S. C. 1997. The Theory of Functional Grammar, Vol. 2: Complex and Derived Constructions. Edited by K. Hengeveld. Berlin and New York: Mouton de Gruyter.

Faber, P. and R. Mairal (forthcoming). "Reconsidering lexical representations in Functional Grammar".

Fischer, O., A. Van Kemenade, W. Koopman and W. Van der Wurff. 2000. The Syntax of Early English. Cambridge: Cambridge University Press.

Foley, W., and R. Van Valin. 1984. Functional Syntax and Universal Grammar. Cambridge: Cambridge University Press.

Goossens, L. 1990a. "Metaphtonymy: the interaction of metaphor and metonymy in expressions for linguistic action". Cognitive Linguistics 1-3: 323-340.

Goossens, L. 1990b. "Mental processes and relational verbs and the typology of states of affairs in FG", in: M. Hannay and E. Vester (eds.), Working with Functional Grammar: Descriptive and Computational Applications. Dordrecht: Foris. 167-186.

Hengeveld, K. 1989. "Layers and operators in Functional Grammar". Journal of Linguistics 25: 127-157.

Hengeveld, K. 1990. "The hierarchical structure of utterances", in: Nuyts, Bolkestein and Vet (eds.), 1-23.

Hoekstra, T., H. van der Hulst and M. Moortgat (eds.). 1981. Perspectives on Functional Grammar. Dordrecht: Foris.

Kalisz, R., and W. Kubinski. 1997. "Functional Grammar vs. Cognitive Linguistics: an attempt at discovering similarities and differences", Working Papers in Functional Grammar 64. Amsterdam: University of Amsterdam.

Kiparsky, P. 1998. "Partitive Case and Aspect", in M. Butt and W. Geuder (eds.), The Projection of Arguments. Lexical and Compositional Factors. Stanford, California: CSLI Publications. 265-307.

Mairal, R. and R. D. Van Valin (2001). "What Role and Reference Grammar can do for Functional Grammar", in: M.J. Pérez Quintero (ed.), Challenges and Development in Functional Grammar. Revista Canaria de Estudios Ingleses, 42. La Laguna: Servicio de Publicaciones de la Universidad de La Laguna. 
Martín Arista, J. 1999. "Expresión y motivación en Gramática Funcional", in: C. Butler, R. Mairal Usón, J. Martín Arista and Francisco Ruiz de Mendoza, Nuevas Perspectivas en Gramática Funcional. Barcelona: Ariel. 173-217.

Martín Arista, J. 2001a. "Sintaxis Medieval I: Complementación, caso y sintaxis verbal", in: I. De la Cruz and J. Martín Arista, eds. Lingüística bistórica inglesa. Barcelona: Ariel. 224-312.

Martín Arista, J. 2001b. "Sintaxis Medieval II: Funciones, construcciones y orden de constituyentes", in: I. De la Cruz and J. Martín Arista, eds. Lingüística bistórica inglesa. Barcelona: Ariel. 224-312.

McLaughlin, J. C. 1983. Old English Syntax: A Handbook. Tübingen: Niemeyer.

Michaelis, L. A. 1993. "On Deviant Case-Marking in Latin", in: R.D. Van Valin (ed.). Advances in Role and Reference Grammar. Amsterdam: John Benjamins. 311-373.

Mitchell, B. 1985. Old English Syntax (2 vols.). Oxford and New York: Clarendon Press.

Nuyts, J. 1992. Aspects of a Cognitive-Pragmatic Theory of Language. Amsterdam: John Benjamins.

Nuyts, J., A. M. Bolkestein and C. Vet (eds.). 1990. Layers and Levels of Representation in Language Theory. Amsterdam: John Benjamins.

Pinkster, H. 1990 (1988). Latin Syntax and Semantics. London and New York: Routledge.

Pyles, T. and J. Algeo. 1982. The Origins and Development of the English Language. San Diego: Harcourt Brace Jovanovich.

Rissanen, M. and O. Ihalainen. 1984. The Helsinki Corpus of English Texts. Diachronic and Dialectal. Helsinki: University of Helsinki.

Roberts, L. 1995. "Pivots, voice and macroroles: from Germanic to universal grammar". Australian Journal of Linguistics 15: 157-214.

Talmy, L. 1988. "Force Dynamics in Language and Cognition". Cognitive Science 12: 49-100.

Taylor, J.R. 1989. Linguistic Categorization. Oxford: Oxford University Press.

Van Valin, R. D. 1990. "Layered Syntax in Role and Reference Grammar", in: Nuyts, Bolkestein and Vet (eds.), 193-231.

Van Valin, R. D. 1991. "Another look at Icelandic case marking and grammatical relations". Natural Language and Linguistic Theory 9: 145-194.

Van Valin, R. D., and R. LaPolla. 1997. Syntax: Structure, Meaning and Function. Cambridge: Cambridge University Press. 